\title{
QUESTIONÁRIO SOBRE INTELECTUAIS E ANTI-INTELECTUALISMO: UM BALANÇO
}

Em outubro de 2018, na ocasião da chamada para contribuições para a Revista Malala n. 10, dedicada ao tema dos intelectuais e ao fenômeno do anti-intelectualismo, lançamos algumas perguntas e convidamos a comunidade acadêmica, os leitores da revista e o Conselho Editorial a respondê-las.

Agradecemos aos que participaram e aqui apresentamos um resumo dos resultados:

Perguntamos abertamente o que é um intelectual e a linha de resposta mais presente foi a relação que os intelectuais têm com o conhecimento, seja diante de conhecer seu lugar no mundo, seja de divulgar um conhecimento conquistado graças a um lastro cultural (erudição, aprofundamento em temas de pesquisa etc.)

Outro ponto que questionamos foi no que diz respeito à filiação/adesão dos intelectuais seja a uma ideologia, seja a um movimento político. Nas respostas, destaca-se a adesão por afinidade, pela busca de reconhecimento dos pares, desejo de mudança e pela cultura política. E, quando cogitamos a possibilidade de rompimento, encontramos como balizas: a busca por coerência, a ameaça de uma perseguição e o encontro, confrontação diante de paradoxos, contradições que levariam o intelectual a reavaliar sua posição.

Quando questionamos se intelectuais escolhem se serão de direita ou esquerda, a pergunta parece ter gerado certo incômodo. Alguns ponderaram que caberia aos intelectuais conhecer ambos os lados, entendê-los e levar essa divergência em consideração em suas posições; outros consideram descabido considerar uma escolha ideológica. Uma das respostas lembrou-se da trajetória dos neoconservadores, um grupo de intelectuais dos EUA que se diziam de esquerda nos anos de 1950 e 1960, "mudando de lado" - alguns radicalmente, outros gradualmente - e chegando ao poder em governos conservadores nos anos de 1980 até recentemente, entre 2002 e 2006. Segundo um dos pais do neoconservadorismo, Irving Kristol, em diálogo com sua própria juventude trotskista, todo intelectual é, por definição, de esquerda.

Também houve questionamentos sobre a relação entre intelectuais e a legitimação da violência. Os intelectuais são responsáveis pela violência que eventualmente é cometida em nome de "ideias" ou revoluções defendidas por eles? Nas respostas, destacase a demarcação "moralmente, sim; juridicamente, nem sempre". Outro ponto recorrente nas respostas é o lembrete de que "ideias têm consequências", mas os contextos político, cultural, social são variáveis complexas que os intelectuais - por mais que eventualmente achem que sim - nem sempre conseguem prever ou controlar, o que levou alguns a pensar em outro tema, o da "liberdade de expressão". Se os intelectuais geram, alimentam e incentivam violência, logo é preciso censurar o que dizem? Em uma das respostas, 


\section{apresentação}

encontramos: "Não creio, contudo, que a culpa seja desta livre expressão, mas sim da ignorância e do simplismo (das pessoas)".

Perguntamos por inspirações intelectuais e recebemos de volta: Adam Nergal Darski, Chimamanda Adichie, Hannah Arendt, Edward Said e Perry Anderson. E, quando perguntamos pelos mais influentes de nosso tempo: Habermas foi dos mais citados, além de Yuval Noah Harari, Fareed Zakaria e Nassim Nicholas Taleb.

Quando o tema foi anti-intelectuais, Donald Trump foi lembrado pela maioria; o ex-presidente do Brasil Luiz Inácio Lula da Silva também foi citado, assim como outros fizeram referência a regimes totalitários, especialmente ao fascismo e ao nazismo.

Perguntados sobre a utopia de nosso tempo, tivemos respostas intrigantes: o islamismo, a equidade de gênero, a tese hegeliana (reapresentada por Fukuyama no final dos anos de 1990) do "fim da história", o fim da corrupção e a possibilidade de "paz" entre pessoas, nações e povos.

Também pedimos para as pessoas responderem a algumas perguntas fechadas, cujas respostas, já divididas em gráficos, são apresentadas a seguir:

11) Na sua opinião, qual a principal dificuldade enfrentada na carreira acadêmica?

6 responses

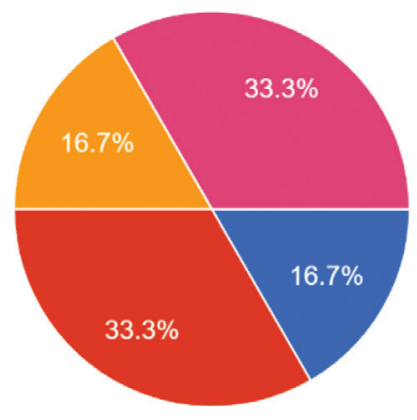

Falta de dinheiro
Falta de estabilidade
Lidar com a burocracia universitária
A Relação com estudantes /
orientandos
Dificuldade de internacionalizar o
debate
Baixo ou ausência de reconhecimento
social
Solidão / Ansiedade / Alta competiti...

12) Na sua opinião o debate intelectual internacional sobre Oriente Médio Mundo Muçulmano (OMMM) é predominantemente pautado pelos:

7 responses

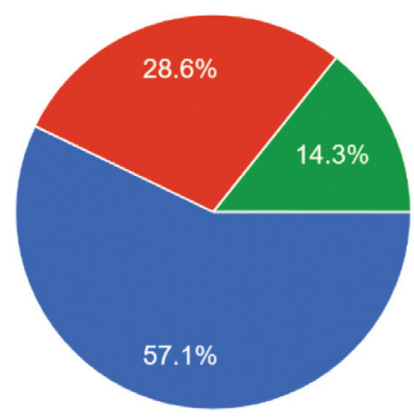

Intelectuais ocidentais

Intelectuais pós-coloniais

Intelectuais multiculturalistas

Intelectuais marxistas ou pós-

marxistas 


\section{apresentação}

13) Já o debate feito no Brasil sobre OMMM é pautado por:

7 responses

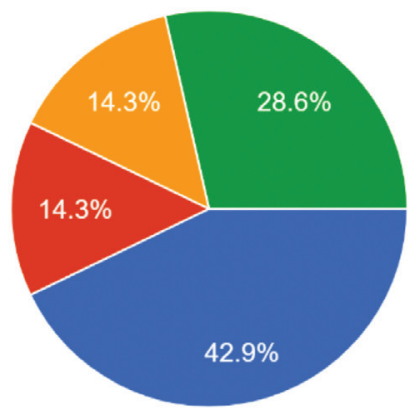

Intelectuais ocidentais

Pós- Coloniais

Multiculturalistas

Marxistas ou Pós-Marxistas

14) A linha editorial da Revista Malala é mais próxima da vertente:

7 responses

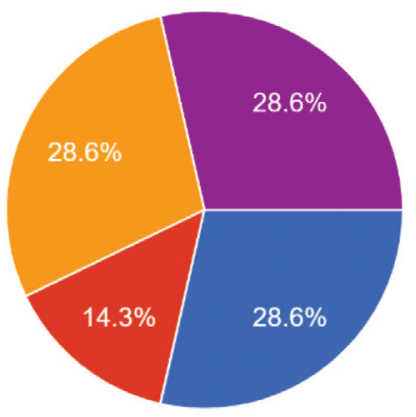

Dos intelectuais que pensam o

OMMM pela perspectiva Ocidental

Pós-Colonial

Muliculturalista

- Marxista / Pós-marxista

Outra

A todos que participaram dessa pesquisa nosso muito obrigado.

Comissão Editorial ${ }^{1}$ da Revista Malala, março/2019

${ }^{1}$ Ariel Finguerut (doutor, Ciência Política/Unicamp), Natalia Calfat (doutoranda, Ciência Política/USP) e Cila Lima (doutora, História Social/USP). 